\title{
Ductal Carcinoma In Situ in Pregnant Women
}

\author{
Akiko Chiba' ${ }^{*}$, Emily E. Bunce ${ }^{2}$ \\ 'Department of Surgery, Division of Surgical Oncology, Wake Forest School of Medicine, Winston-Salem, NC, USA \\ 'Section on Maternal Fetal Medicine, Department of Obstetrics and Gynecology, Wake Forest School of Medicine, Winston-Salem, \\ NC, USA
}

*Corresponding author: Akiko Chiba, Assistant Professor Department of Surgery Division of Surgical Oncology Wake Forest School of Medicine Winston-Salem, NC, USA

E-Mail:achiba@wakehealth.edu
Received: 22.10 .2021

Accepted: 30.11 .2021

\section{Rezumat}

Cancerul mamar este a doua cea mai frecventă neoplazie care afectează femeile gravide. În literatura actuală există date limitate cu privire la opțiunile terapeutice pentru carcinomul ductal in situ (CDIS) în sarcină. Deoarece incidența cancerului mamar în sarcină este în creştere, această temă este de interes. În Statele Unite ale Americii una din 3000 de femei însărcinate este diagnosticată cu cancer mamar. Majoritatea femeilor cu CDIS sunt diagnosticate prin screening, deoarece acestea sunt asimptomatice. Intrucât screening-ul de rutină prin mamografie nu este recomandat în timpul sarcinii, diagnosticul de CDIS fără patologie invazivă este rar la femeile gravide. Cancerul mamar în sarcină reprezintă $0.2-3.8 \%$ din toate cazurile de cancer mamar nou diagnosticate. Această raportare nu diferențiază cazurile de CDIS de cele cu cancer mamar invaziv, astfel este dificil de stabilit adevărata incidență a CDIS în sarcină. Acest review sintetizează recomandările multidisciplinare actuale privind tratamentul optim al CDIS diagnosticat în timpul sarcinii.

Cuvinte cheie: carcinomul ductal in situ, sarcina, diagnostic, tratament

\section{Abstract}

Breast cancer is the second most common malignancy affecting pregnant women. Ductal carcinoma in situ (DCIS) during pregnancy has not been well described with limited literature addressing the optimal treatment options. This is important topic 
as the incidence of pregnancy-associated breast cancer (PABC) has been increasing. In the United States, 1 in 3000 pregnancies are complicated by breast cancer diagnosis. Most DCIS are screen detected as most patients are asymptomatic. Since routine screening mammogram is not recommended during pregnancy, diagnosis of DCIS without invasive disease is uncommon diagnosis. Although PABC is reported to account for $0.2-3.8 \%$ of all newly diagnosed breast cancer, it has not been defined between the diagnosis of DCIS or invasive breast cancer making true incidence of DCIS in pregnancy difficult to report. This review summarizes multidisciplinary recommendations for optimal treatment for DCIS diagnosed during pregnancy.

Key words: ductal carcinoma in situ, pregnancy, diagnosis, treatment

\section{Introduction}

Breast cancer is the second most common malignancy affecting pregnant women following cervical cancer (1-3). Pregnancy-associated breast cancer (PABC) was understood as carcinoma of the breast in pregnant and breastfeeding patients. The commonly used definition is breast cancer diagnosis during gestation and or within one year of childbirth $(4,5)$, however, some would consider up to 2 years postpartum as PABC $(6,7)$. Ductal carcinoma in situ (DCIS) during pregnancy has not been well described and there was limited literature addressing the optimal management and treatment options. For the purpose of this review, we are focused on the management of the pregnant patient with DCIS. The goal of this review is to summarize the care of the pregnant patient with DCIS including diagnostic, surgical, and adjuvant therapeutic perspectives of radiation and systemic therapy in this unique population. Herein, we provide practical guidance to the optional treatment approach to patients diagnosed with DCIS during pregnancy.

\section{Incidence}

The incidence of PABC has been increasing. In the United States, 1 in 3000 pregnancies are complicated by breast cancer (8) The average age of women with $\mathrm{PABC}$ ranges from age 32 to 38 years $(9,10)$. A large population study conducted in Sweden showed the number of
PABC cases doubled from 16.0 to 37.4 cases per 100,000 deliveries between 1963 to 20026 . This increase is likely due to many women postpone their first delivery to obtaining advanced education and being focused on their career path. The age at first gestation has increased from 24.9 years in 2000 to 26.3 years in 2014 (11). Having first gestation after age 30 has been established as increased risk of breast cancer and has been acknowledged ask a risk factor or $\operatorname{PABC}(9,12,13)$. Therefore leading to delay in childbearing and increasing the incidence of PABC. Although PABC is reported to account for $0.2-3.8 \%$ of all newly diagnosed breast cancer, (14) it has not been defined between the diagnosis of DCIS or invasive breast cancer making true incidence of DCIS in pregnancy difficult to report. Result from Colon et al reported DCIS constituted $12.4 \%$ of all carcinoma in young women less than 40 and $18.3 \%$ of all carcinoma in women aged 40 and over (15), however, they did not report if any of these patients under 40 were diagnosed during their pregnancy. Incidence of DCIS during pregnancy has not been reported.

\section{Diagnosis}

Breast cancer during pregnancy is usually diagnosed by patients or physicians due to having symptoms such as palpable mass, pain or nipple discharge 9 as pregnant patients are usually not receiving screening breast imaging. The diagnosis of $\mathrm{PABC}$ is often 
delayed by up to 13 months after the appearance of symptoms (16). Delays in the diagnosis are likely due to pregnancy-induced breast changes such as breast engorgement, which makes concerning symptoms difficult to differentiate from normal physiologic changes of the breast tissue. Those with PABC were twice as likely to be diagnosed with a higher stage with T3 to T4 disease (17) making diagnosis of DCIS rare event. Most DCIS are screen detected as most patients are asymptomatic. Since routine screening mammogram is not recommended during pregnancy, diagnosis of DCIS without invasive disease is uncommon diagnosis. Women older than 40 are recommended to return to screening mammogram 3 months after completion of breast feeding to allow their breast to return to baseline density.

\section{Workup of Breast Abnormality}

Breast ultrasound is the recommended fistline modality for workup of breast symptoms in a pregnant patient due to its lack of ionizing radiation and a high sensitivity (18). The utility of ultrasound in detecting malignancy in pregnant patients has been reported to be $100 \%$ sensitive (19-21) and 100\% negative predictive value (19). In addition, ultrasound ca be used to differentiate benign palpable breast masses in these patients. If the ultrasound demonstrates suspicious findings, diagnostic mammogram should be performed followed by core needle biopsy for pathologic evaluation (Fig. 1). Mammography is considered to be safe during pregnancy with appropriate abdominal shielding. Bilateral two-view digital mammogram exposes less than 3 mGy radiation which is equivalent to the average background radiation over 7 weeks of background radiation (22). The estimated dose to the uterus exposure is less than $0.03 \mathrm{~Gy}$, (23) which is significantly below the acceptable fetal exposure which is $<50,000$ Gy (24). The sensitivity of mammogram is low in women under the age of 40 due to increased parenchymal density of the breast tissue (25). However, mammography is helpful in evaluat- ing the contralateral breast as well as detection of microcalcifications which may not be visualized on ultrasound. Since microcalcification is the most common imaging abnormality found in patients with DCIS, imaging evaluation with mammography is recommended (26). Contrast-enhanced MRI during pregnancy is contra-indicated due to the use of gadoliniumbased contrast. Gadolinium contrasts are classified as pregnancy category $\mathrm{C}$ by the U.S. Food and Drug Administration (FDA) as it will cross the placenta.

Pathologic tissue diagnosis is recommended when suspicious abnormality has been identified by ultrasound or with mammogram. Ultrasound guided core needle biopsy is preferred to

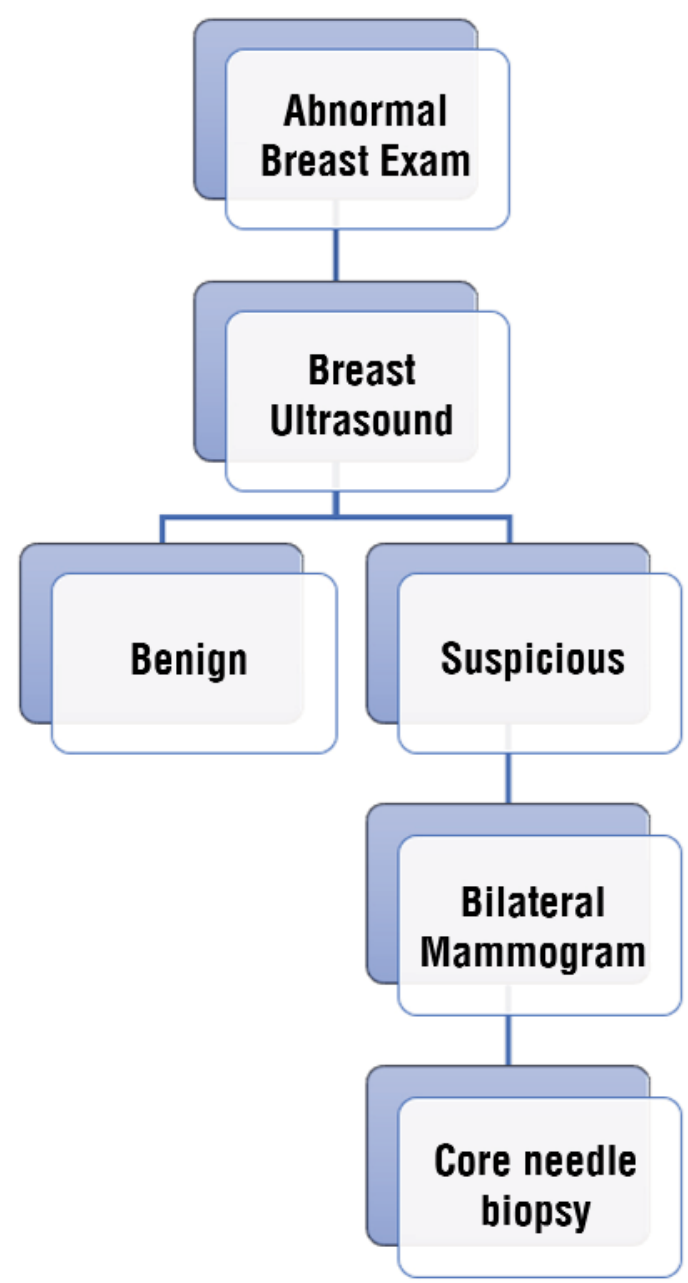

Figure 1. Work-up of breast abnormality during pregnancy 
stereotactic biopsy due to no added risk of ionizing radiation, however, stereotactic biopsy and mammographic guided wire localization are safe during pregnancy. The use of local anesthetic with lidocaine as no increased risk to the fetus. The risk of milk fistula rate has be reported to be rare complication of large bore core needle biopsy (27).

\section{Treatment}

The aims of treatment of breast cancer should be the same for pregnant and nonpregnant women. However, once a diagnosis of DCIS has been made, it is important to consider where the patient is in her pregnancy to determine treatment options. If the patient is near term, it is reasonable to proceed with delivery prior to starting treatment. If the patient is early in her pregnancy (first or second trimester), treatment may be initiated in the second trimester after evaluating imaging findings. There has been no evidence to suggest termination of pregnancy affects survival outcome (28). The majority of PABCs and pregnancies occur in women under age 45 , therefore the possibility of genetic mutation carrier should be considered. All women younger than 45 years with newly diagnosed breast cancer should be offered genetic testing.

Despite being considered non-invasive disease, and often defined as Stage 0 breast cancer, conventional management include breast-conserving surgery followed by radiation or mastectomy in addition. In addition, adjuvant endocrine therapy maybe recommended. There has been concerns regarding overtreatment of DCIS in the recent years $(29,30)$. Several recent studies suggest that patients with low-grade DCIS may have similar overall survival outcome with or without surgery $(31,32)$. There are three active clinical trials (LORIS ((LORIS (United Kingdom, NCT02766881), COMET (United States, NCT02926911)33 and LORD (The Netherlands, NCT02492607)) randomizing patients to active surveillance and standard of treatment. These trials likely would not apply to pregnant patients with DCIS as the eligibility age for these studies is over 40-46 and only low to intermediate grade DCIS are included. Based on these ongoing clinical trials, delay in treatment until delivery maybe an option for selected patients.

\section{Surgical Treatment}

The surgical recommendation for pregnant women is similar to women who are not pregnant. Surgical recommendations are based on the extent of the disease. Since treatment of DCIS do not include the need for chemotherapy, surgical intervention is the main stay of the treatment. Based on the extent of disease, patient maybe candidate for breast-conserving surgery. In the case of extensive calcifications patients maybe recommended mastectomy. The role of radiation therapy following breast-conserving surgery in DCIS remains controversial. Breastconserving surgery is limited in first and second trimester for invasive breast cancer due to timing of radiation therapy as radiation is contraindicated during pregnancy. Despite adjuvant radiation decreasing local recurrence rate, it does not affect overall survival or breast-cancer-specific survival for DCIS, therefore the discussion with radiation oncology provider is important as omission of adjuvant radiation maybe considered. There has been recent trials evaluating the use of a biosignature to evaluate recurrence risk to identify patients who may be low risk for recurrence and adjuvant radiation maybe omitted (34).

Performing sentinel lymph node biopsy with lymphoscintigraphy with $99 \mathrm{~m}$-Tc sulfur colloid is safe during pregnancy. Radiation dose to the uterus was calculated to be 1.67

Gy which is significantly below the threshold of acceptable fetal exposure which is $<50,000$ Gy (35-37). The use of isosulfan blue dye is not recommended as this dye is classified as category C by the FDA. Sentinel lymph node biopsy is considered standard of care for patients undergoing mastectomy for DCIS in the clinically negative axilla due to potential upstage to invasive disease. If 
Table 1. Suggested Surgical Management DCIS in Pregnancy

\begin{tabular}{ll}
\hline Time of Diagnosis & Surgical Treatment \\
\hline $1^{\text {st }}$ trimester & $\begin{array}{l}\text { Consider waiting till second trimester, unless imaging concern of upstaging to invasive } \\
\text { disease }\end{array}$ \\
\hline $2^{\text {nd }}$ trimester & - Consider surgery using rapid sequence induction and fetal monitoring \\
\hline $3^{\text {rd }}$ trimester & - Consider surgery using rapid sequence induction and fetal monitoring \\
& - Consider waiting till delivery depending on imaging concern and week of gestation \\
\hline
\end{tabular}

breast-conserving surgery is being considered, sentinel lymph node biopsy is not necessary in the setting of DCIS without invasive component as sentinel lymph node biopsy can be performed later if invasive breast cancer were to be identified.

It has been reported that immediate reconstruction with tissue expander placement after mastectomy maybe feasible and safe. Several studies reported no increased maternal morbidity, obstetrical complications or adverse fetal outcome in patients who underwent immediate reconstruction even with increased operating time with addition of reconstruction $(38,39)$.

Another consideration for surgical treatment is for the patients to undergo breastconserving surgery during pregnancy for the benefit is shorter operating time and allows for breast feeding. Performing mastectomy could be delayed until after delivery especially if the patient wishes to undergo bilateral mastectomy as definitive surgical treatment to avoid radiation or in the setting of pathogenic genetic mutation. There's no contraindication to breastfeeding from the treated breast if breast conservation was performed (40). However, breastfeeding is contraindicated during radiation therapy and tamoxifen.

\section{Anesthetic Considerations for Surgery}

Anesthetic considerations should include the safety of the mother and the fetus. Surgery may be performed at any time during pregnancy, however, it is safest in the second trimester (weeks 12-24 of gestation). It is recommended that mean arterial pressure remain 60 for optimal uterine perfusion. After 20 weeks of gestational age, patient should be positioned with left lateral uterine displacement tilt to avoid aortocaval compression. After 24 weeks of gestation, intraoperative fetal monitoring is recommended (41).

\section{Adjuvant Therapy}

Radiation therapy is contraindicated in pregnancy due to risk of fetal malformations. There maybe a role for adjuvant radiation following breast conservation after delivery depending on the timing of surgery. Radiation is generally recommended to be given within 6 weeks for surgical excision. If mastectomy was performed, most patients will not meet the criteria for post mastectomy radiation.

Tamoxifen is contraindicated during pregnancy and classified as Category D by the FDA. Tamoxifen has been associated with spontaneous abortions, preterm labor, intrauterine growth restriction, genital tract anomalies similar to those who was exposed to diethylstilbestrol (42). Given these findings, tamoxifen is recommended after delivery. Due to lack of safety data regarding excretion of tamoxifen in breast milk, tamoxifen is also not recommended during lactation. The decision to delay endocrine treatment to allow for breastfeeding maybe discussed on individual bases with medical oncologist.

\section{Conclusion}

DCIS during pregnancy is rare diagnosis posing clinically challenging situation for the patients and their physicians. The work up for breast abnormality found during pregnancy should be pursed with ultrasound as the primary modality prior to mammogram. Biopsy and surgery should proceed as if the 
patient is not pregnant with minor modifications depending on the gestational age. The surgical recommendation for pregnant women is similar to women who are not pregnant, however, breast-conserving surgery maybe limited in first and second trimester due to timing of radiation therapy as radiation is contraindicated during pregnancy. A multidisciplinary team approach is recommended for optimal treatment planning. Recommendation should be personalized based on the gestational age, concern for upstage to invasive disease, extent of DCIS, and patient preferences.

\section{Conflict of Interest}

The authors declare no conflicts of interests.

\section{References}

1. Navrozoglou I, Vrekoussis T, Kontostolis E, Dousias V, Zervoudis S, Stathopoulos EN, et al. Breast cancer during pregnancy: a mini-review. Eur J Surg Oncol. 2008;34(8):837-843.

2. Cardonick E. Pregnancy-associated breast cancer: optimal treatment options. Int J Womens Health. 2014;6:935-43.

3. Shachar SS, Gallagher K, McGuire K, Zagar TM, Faso A, Muss HB, et al. Multidisciplinary Management of Breast Cancer During Pregnancy. Oncologist. 2017:22(3):324-334.

4. Amant F, Loibl S, Neven P, Van Calsteren K. Breast cancer in pregnancy. Lancet. 2012;379(9815):570-579.

5. Ruiz R, Herrero C, Strasser-Weippl K, Touya D, Louis JSt, Bukowski A, et al. Epidemiology and pathophysiology of pregnancy-associated breast cancer: A review. Breast. 2017;35:136-141.

6. Andersson TM, Johansson ALV, Hsieh CC, Cnattingius S, Lambe M. Increasing incidence of pregnancy-associated breast cancer in Sweden. Obstet Gynecol. 2009;114(3):568-572.

7. Callihan EB, Gao D, Jindal S, Lyons TR, Manthey E, Edgerton S, et al. Postpartum diagnosis demonstrates a high risk for metastasis and merits an expanded definition of pregnancy-associated breast cancer. Breast Cancer Res Treat. 2013;138(2):549-559.

8. de Haan J, Verheecke M, Van Calsteren K, Van Calster B, Shmakov RG, Gziri MM, et al. Oncological management and obstetric and neonatal outcomes for women diagnosed with cancer during pregnancy: a 20-year international cohort study of 1170 patients. Lancet Oncol. 2018;19(3): 337-346.

9. Molckovsky A, Madarnas Y. Breast cancer in pregnancy: a literature review. Breast Cancer Res Treat. 2008;108(3):333-338.

10. Brooks JD, Boice JD Jr, Stovall M, Reiner AS, Bernstein L, John EM, et al. Reproductive status at first diagnosis influences risk of radiation-induced second primary contralateral breast cancer in the WECARE study. Int $\mathrm{J}$ Radiat Oncol Biol Phys. 2012;84(4):917-924.

11. Mathews TJ, Hamilton BE. Mean Age of Mothers is on the Rise: United States, 2000-2014. NCHS Data Brief. 2016(232):1-8.

12. Moreira WB, Brandăo EC, Soares AN, Lucena CE, Antunes CM. Prognosis for patients diagnosed with pregnancy-associated breast cancer: a paired case-control study. Sao Paulo Med J. 2010;128(3):119-124.
13. Albrektsen G, Heuch I, Hansen S, Kvțte G. Breast cancer risk by age at birth, time since birth and time intervals between births: exploring interaction effects. Br J Cancer. 2005;92(1):167-175.

14. Wallack MK, Wolf JA, Jr, Bedwinek J, Denes AE, Glasgow G, Kumar B, et al. Gestational carcinoma of the female breast. Curr Probl Cancer. 1983;7(9): $1-58$.

15. Conlon N, Howard J, Catalano J, Gallagher M, Tan LK, Corben AD. Breast Carcinoma in Young Women: No Evidence of Increasing Rates of Metastatic Breast Carcinoma in a Single Tertiary Center Review. Breast J. 2016; 22(3):287-292

16. Kim YG, Jeon $Y W$, Ko BK, Sohn G, Kim EK, Moon BI, et al. Clinicopathologic Characteristics of Pregnancy-Associated Breast Cancer: Results of Analysis of a Nationwide Breast Cancer Registry Database. J Breast Cancer. 2017;20(3):264-269.

17. Pilewskie M, Gorodinsky P, Fought A, Hansen N, Bethke K, Jeruss J, et al. Association between recency of last pregnancy and biologic subtype of breast cancer. Ann Surg Oncol. 2012;19(4):1167-73.

18. Woo JC, Yu T, Hurd TC. Breast cancer in pregnancy: a literature review. Arch Surg. 2003;138(1):91-98; discussion 99 .

19. Ahn BY, Kim HH, Moon WK, Pisano ED, Kim HS, Cha ES, et al. Pregnancyand lactation-associated breast cancer: mammographic and sonographic findings. J Ultrasound Med. 2003;22(5):491-497; quiz 498-499.

20. Robbins J, Jeffries D, Roubidoux M, Helvie M. Accuracy of diagnostic mammography and breast ultrasound during pregnancy and lactation. AJR Am J Roentgenol. 2011;196(3):716-722.

21. Liberman L, Giess CS, Dershaw DD, Deutch BM, Petrek JA. Imaging of pregnancy-associated breast cancer. Radiology. 1994;191(1):245-248.

22. Hendrick RE, Pisano ED, Averbukh A, Moran C, Berns EA, Yaffe MJ, et al. Comparison of acquisition parameters and breast dose in digital mammography and screen-film mammography in the American College of Radiology Imaging Network digital mammographic imaging screening trial. AJR Am J Roentgenol. 2010;194(2):362-9.

23. Sechopoulos I, Suryanarayanan S, Vedantham S, D'Orsi CJ, Karellas A. Radiation dose to organs and tissues from mammography: Monte Carlo and phantom study. Radiology. 2008;246(2):434-443.

24. Psyrri A, Burtness B. Pregnancy-associated breast cancer. Cancer J. 2005; 11(2):83-95.

25. Conant EF, Barlow WE, Herschorn SD, Weaver DL, Beaber EF, Tosteson A NA, et al. Association of Digital Breast Tomosynthesis vs Digital Mammography With Cancer Detection and Recall Rates by Age and Breast Density. JAMA Oncol. 2019;5(5):635-642.

26. Yang WT, Dryden MJ, Gwyn K, Whitman GJ, Theriault R. Imaging of breast cancer diagnosed and treated with chemotherapy during pregnancy. Radiology. 2006;239(1):52-60.

27. Schackmuth EM, Harlow CL, Norton LW. Milk fistula: a complication after core breast biopsy. AJR Am J Roentgenol. 1993;161(5):961-962.

28. Jacobs IA, Chang CK, Salti Gl. Coexistence of pregnancy and cancer. Am Surg. 2004;70(11):1025-1029.

29. Esserman LJ, Thompson IM, Jr., Reid B. Overdiagnosis and overtreatment in cancer: an opportunity for improvement. Jama. 2013;310(8):797-798.

30. Bleyer A, Welch HG. Effect of three decades of screening mammography on breast-cancer incidence. N Engl J Med. 2012;367(21):1998-2005.

31. Narod SA, Iqbal J, Giannakeas V, Sopik V, Sun P. Breast Cancer Mortality After a Diagnosis of Ductal Carcinoma In Situ. JAMA Oncol. 2015;1(7):888896.

32. Worni M, Akushevich I, Greenup R, Sarma D, Ryser MD, Myers ER, et al. Trends in Treatment Patterns and Outcomes for Ductal Carcinoma In Situ. J Natl Cancer Inst. 2015;107(12):djv263.

33. Hwang ES, Hyslop T, Lynch T, Frank E, Pinto D, Basila D, et al. The COMET (Comparison of Operative versus Monitoring and Endocrine Therapy) trial: a phase III randomised controlled clinical trial for low-risk ductal carcinoma in situ (DCIS). BMJ Open. 2019;9(3):e026797.

34. Shah C, Bremer T, Cox C, Whitworth P, Patel R, Patel A, et al. The Clinical Utility of DCISionRT $®$ on Radiation Therapy Decision Making in Patients 
with Ductal Carcinoma In Situ Following Breast-Conserving Surgery. Ann Surg Oncol. 2021;28(11):5974-5984.

35. Keleher A, Wendt R, 3rd, Delpassand E, Stachowiak AM, Kuerer HM. The safety of lymphatic mapping in pregnant breast cancer patients using Tc-99m sulfur colloid. Breast J. 2004;10(6):492-495.

36. Morita ET, Chang J, Leong SP. Principles and controversies in lymphoscintigraphy with emphasis on breast cancer. Surg Clin North Am. 2000; 80(6):1721-1739.

37. Mondi MM, Cuenca RE, Ollila DW, Stewart JHt, Levine EA. Sentinel lymph node biopsy during pregnancy: initial clinical experience. Ann Surg Oncol. 2007;14(1):218-221.

38. Lohsiriwat V, Peccatori FA, Martella S, Azim HA Jr, Sarno MA, Galimberti V, et al. Immediate breast reconstruction with expander in pregnant breast cancer patients. Breast. 2013;22(5):657-60.

39. Caragacianu DL, Mayer EL, Chun YS, Caterson S, Bellon JR, Wong JS, et al. Immediate breast reconstruction following mastectomy in pregnant women with breast cancer. J Surg Oncol. 2016;114(2):140-3.

40. Jones AL. Management of pregnancy-associated breast cancer. Breast. 2006;15 Suppl 2:S47-52.

41. Macdonald HR. Pregnancy associated breast cancer. Breast J. 2020; 26(1):81-85.

42. Clark JH, McCormack SA. The effect of clomid and other triphenylethylene derivatives during pregnancy and the neonatal period. J Steroid Biochem. 1980;12:47-53. 